\title{
PENINGKATAN KETRAMPILAN MAHASISWA DALAM PENGELOLAAN SAMPAH ORGANIK UNTUK MEWUJUDKAN GREEN CAMPUS DI UNIVERSITAS LANCANG KUNING
}

\author{
Martala Sari*1, Sri Utami Lestari ${ }^{2}$, Raudhah Awal ${ }^{3}$ \\ ${ }^{1,3}$ Program Studi Pendidikan Biologi FKIP Universitas Lancang Kuning, \\ ${ }^{2}$ Program Studi Agroteknologi FAPERTA Universitas Lancang Kuning \\ Jln. Yossudarso KM. 8 Rumbai- Pekanbaru Riau \\ *E-mail: martalasari@unilak.ac.id
}

\begin{abstract}
Activity Organic waste management is a manifestation to go to Green Campus is one of the activities to realize the creation of a good environment and can be utilized for the campus community. Many plants that have campus less optimal growth so that fertilization needs. For that need to invite campus community, especially students to make organic fertilizer by utilizing the existing waste in the campus environment or canteen and household waste that can be used as compost. Need further training so that students are more aware of the waste management.
\end{abstract}

Keyword-Training, Compos, Waste Manage

\begin{abstract}
Abstrak
Kegiatan Pengelolaan sampah organik merupakan perwujudan untuk menuju Green Campus merupakan salah satu kegiatan untuk mewujudkan terciptanya lingkungan yang baik dan dapat dimanfaatkan bagi masyarakat kampus. Banyak tanaman yang ada dikampus yang kurang optimal pertumbuhan sehingga perlu pemupukan. Untuk itu perlu mengajak masyarakat kampus khususnya mahasiswa untuk membuat pupuk organik dengan memanfaatkan sampah yang ada di lingkungan kampus atau kantin dan sampah rumah tangga sehingga dapat dimanfaatkan sebagai pupuk kompos. Perlu pelatihan lebih lanjut sehingga siswa lebih paham terhadap pengelolaan sampah tersebut.
\end{abstract}

Kata kunci-Pelatihan, Kompos, Pengelolaan Sampah

\section{PENDAHULUAN}

Sampah merupakan salah satu permasalahan lingkungan yang memerlukan penanganan serius. Berdasarkan Undang-Undang No. 18 Tahun 2008, sampah adalah sisa kegiatan sehari-hari manusia dan atau proses alam yang berbentuk padat. Secara umum sampah dibedakan menjadi tiga, yaitu sampah organik/basah, sampah anorganik/kering, dan sampah berbahaya (Sejati,2009). Seiring dengan meningkatnya jumlah penduduk di suatu wilayah maka juga mengakibatkan bertambahnya volume sampah. Pola konsumsi masyarakat ikut memberi kontribusi dalam peningkatan volume sampah yang semakin beragam jenisnya. Sampah rumah tangga merupakan salah satu sumber sampah yang cukup besar peranannya dalam peningkatan volume sampah di suatu lingkungan.

Kegiatan ini bertujuan untuk menanamkan kecintaan warga kampus pada lingkungan hidupnya, termasuk menanamkan sikap dan perilaku yang peduli dan berbudaya lingkungan. Untuk menciptakan suasana akademik kampus yang natural dan green campus, maka kegiatan ini perlu dilaksanakan. Sehingga tim pengabdian ingin memberikan arahan dalam pelatihan pengelolaan sampah yang terdapat disekolah itu dan sampah yang dipilah dapat dijadikan pupuk kompos yang dapat digunakan sekolah dalam menanam tanaman pelindung dikampus FKIP.

Peran masyarakat dalam pengelolaan sampah diperlukan tidak hanya sebatas dalam membuang sampah di tempat yang seharusnya, namun diharapkan termasuk juga pengolahan sampah yang memberikan manfaat kembali bagi masyarakat itu sendiri. Mitra pada pengabdian ini adalah 
mahasiswa Himpunan Mahasiswa Program Studi Pendidikan Biologi (HIMABIO) dan Mahasiswa HIMAAGROTEKNOLOGI, yang turut berperan serta sebagai masyarakat dalam pengelolaan sampah. Hal ini diperlukan tidak hanya sebatas dalam membuang sampah di tempat yang seharusnya, namun diharapkan termasuk juga pengolahan sampah yang memberikan manfaat kembali bagi masyarakat itu sendiri.

\section{METODE}

Metode pelaksanaan kegiatan pengabdian kepada masyarakat ini dilakukan berdasarkan langkah-langkah berikut:

1. Melakukan tahap analisis situasi berupa observasi lapangan dan wawancara dengan mahasiswa.

2. Mengidentifikasi permasalahan mitra untuk dicarikan solusinya.

3. Melaksanakan pelatihan pengelolaan sampah dan pembuatan pupuk kompos sebagai solusi atas permasalahan para mahasiswa di kampus mitra. Kegiatan pelatihan dilakukan sebanyak 2 sesi.

a. Pada sesi pertama, para mahasiswa di kampus mitra akan diberikan pembekalan ilmu tentang pengelolaan sampah, dengan cara memisahkan sampah organik dan sampah anorganik. Serta penjelasan tentang pembuatan pupuk kompos dengan menggunakan metode sederhana.

b. Pada sesi kedua, melakukan demontrasi cara membuat pupuk kompos dengan menggunakan metode sederhana. pembuatan pupuk kompos dengan menggunakan metode sederhana sudah dijelaskan sebelumnya. Bahan pembekalan diambil dari berbagai sumber terkait.

4. Memberikan kesempatan bertanya dan berdiskusi selama kegiatan pelatihan berlangsung.

\section{HASIL DAN PEMBAHASAN}

Hasil kegiatan pelatihan peningkatan keterampilan mahasiswa dalam pengelolaan sampah organik untuk mewujudkan green campus di Universitas Lancang Kuning membawa dampak yang positif bagi masyarakat kampus. Hal ini terbuktikan dengan berhasilnya pembuatan pupuk kompos yang telah dibuat dengan menggunakan metode sederhana yang dilaksanakan oleh mahasiswa Himpunan Mahasiswa.

Himpunan Mahasiswa (HIMA) melakukan kegiatan pengabdian ini dilokasi kampus FKIP UNILAK yang dipantau oleh tim pengabdian. Kegiatan ini merupakan penambahan masukkan bagi mahasiswa yang dapat dijadikan program kreativitas sehingga memberikan peluang kerja bagi mahasiwa yang ingin berbisnis dalam pupuk kompos. Dalam kegiatan ini juga banyak hal yang akan di pelajari seperti pembuatan Pupuk Organik Cair (POC), Mikroorganisme Lokal (MOL).

Kegiatan pelatihan peningkatan ini diadakan selama 1 hari. Kegiatan pengabdian ini mencakup penyampaian materi (Presentasi) serta demonstrasi dan praktik. Kegiatan tahap 1 berupa Kegiatan presentasi materi dilaksanakan pada pagi harinya, adapun materi presentasi yang diberikan meliputi masalah nasional mengenai penumpukan sampah, pengertian sampah, komposisi sampah, dampak negatif yang akan ditimbulkan oleh penumpukan sampah dan potensi pemanfaatan sampah dan teknologi sederhana pengolahan sampah menjadi kompos serta masalah dan solusi dalam pembuatan kompos. Kegiatan tahap 2 yaitu kegiatan demontrasi yang dilaksanakan pada siang hari nya. Kegiatan demontrasi ini memperagakan langkah-langkah pembuatan kompos sederhana yang berasal dari limbah sampah rumah tangga.

Kegiatan tahap 3 yaitu kegiatan praktik yang akan dilakukan oleh peserta pelatihan yang terdiri dari 17 orang dan terbagi menjadi 4 kelompok. Pada tahapan ini peserta diberikan kebebasan untuk mencari sampah organik yang berada disekitar kampus Universitas Lancang Kuning untuk mereka jadikan sebagai bahan untuk pengomposan 
DINAMISIA - Jurnal Pengabdian Kepada Masyarakat Vol. 2, No. 2 Desember 2018, Hal. 193-196

\section{Evaluasi kegiatan pelatihan}

Evaluasi kegiatan pelatihan ini dilakukan dengan membagikan angket yang harus diisi oleh peserta sebelum dan setelah acara pelatihan selesai. Jika ada peserta yang kesulitan dalam memahami dan menjawab pertanyaan dalam angket tersebut, peserta dibantu oleh rekan-rekan anggota penelitian yang terlibat dalam kegiatan ini. Angket pretes respon peserta pelatihan terhadap kegiatan pengabdian peningkatan keterampilan mahasiswa dalam pengelolaan sampah organik untuk mewujudkan green campus ini dapat dilihat pada Tabel 1 berikut:

Tabel 1. Angket Pretest respon peserta pelatihan terhadap Kegiatan pengabdian Peningkatan Keterampilan Mahasiswa Dalam Pengelolaan Sampah Organik Untuk Mewujudkan Green Campus

\begin{tabular}{clll}
\hline No & \multicolumn{1}{c}{ Pertanyaan } & \multicolumn{1}{c}{ Ya } & \multicolumn{1}{c}{ Tidak } \\
1 & $\begin{array}{l}\text { Apakah anda pernah mengikuti pelatihan pembuatan kompos } \\
\text { sejenisnya? }\end{array}$ & $2(12 \%)$ & $15(88 \%)$ \\
2 & Apakah anda pernah menggunakan kompos sebagai media tanam? & $2(12 \%)$ & $15(88 \%)$ \\
3 & Apakah pembuatan kompos merupakan hal baru Anda? & $2(12 \%)$ & $15(88 \%)$ \\
4 & Apakah anda bisa membuat kompos sendiri? & - & $17(100 \%)$ \\
5 & Apakah pembuatan kompos adalah hal yang memberatkan bagiAnda? & $15(88 \%)$ & $2(12 \%)$ \\
6 & Apakah kegiatan ini dapat meningkatkan pengetahuan anda? & $17(100 \%)$ & - \\
7 & Apakah materi yang diberikan bisa anda pahami denganbaik? & $17(100 \%)$ & - \\
8 & Apakah kegiatan pelatihan ini dapat bermanfaat bagi anda? & $17(100 \%)$ & - \\
9 & Apakah anda merasa senang dengan pelatihan yang diberikan? & $17(100 \%)$ & - \\
10 & Apakah kegiatan ini merupakan hal yang menarik bagi Anda? & $17(100 \%)$ & - \\
\hline
\end{tabular}

Dari Tabel 1 diketahui ada $12 \%$ responden yang sudah pernah mengikuti pelatihan tentang kompos dan sudah pernah menggunakan kompos sebagai media tanam. Setelah dikonfirmasi lebih lanjut, responden tersebut merupakan mahasiswa dari Fakultas pertanian yang sudah pernah mendapatkan materi perkuliahan mengenai pembuatan pupuk kompos dari bahan organik. Walaupun mereka sudah pernah dapat materi pelatihan mengenai kompos ini mereka mengaku kegiatan pelatihan ini dapat menambah pengetahuan mereka, terlebih lagi mengenai solusi dari permasalahan pembutan pupuk kompos ini. Seluruh peserta mengatakan harapan mereka dan merasa bahwa kegiatan pelatihan ini dapat meningkatkan pengetahuan, bermanfaat serta merupakan kegatan yang menarik dan menyenangkan bagi mereka. Hal ini menandakan bahwa peserta antusias untuk mengikuti kegiatan pengabdian mengenai peningkatan keterampilan mahasiswa dalam pengelolaan sampah organik untuk mewujudkan green campus.

Selanjutnya setelah kegiatan presentasi dan demontrasi responden kembali diberi angket Posttest, hal ini bertujuan untuk mengetahui seberapa besar pengaruh presentasi dan demontrasi tentang pembutan kompos sederhana terhadap pengetahuan mereka. Pada Tabel 2 disajikan angket posttest respon peserta pelatihan terhadap kegiatan pengabdian peningkatan keterampilan mahasiswa dalam pengelolaan sampah organik untuk mewujudkan green campus.

Tabel 2. Angket Posttest respon peserta pelatihan terhadap Kegiatan pengabdian Peningkatan Keterampilan Mahasiswa Dalam Pengelolaan Sampah Organik Untuk Mewujudkan Green Campus

\begin{tabular}{clcc}
\hline No & \multicolumn{1}{c}{ Pertanyaan } & Ya & Tidak \\
1 & $\begin{array}{l}\text { Apakah anda senang mengikuti pelatihan pembuatan kompos } \\
\text { sejenisnya? }\end{array}$ & $17(100 \%)$ & - \\
2 & Apakah anda akan menggunakan kompos sebagai media tanam? & $17(100 \%)$ & - \\
3 & $\begin{array}{l}\text { Apakah setelah mendapatkan pelatihan pembuatan kompos hal mudah bagi } \\
\text { Anda? }\end{array}$ & $17(100 \%)$ & - \\
\hline
\end{tabular}


DINAMISIA - Jurnal Pengabdian Kepada Masyarakat Vol. 2, No. 2 Desember 2018, Hal. 193-196

\begin{tabular}{cllc}
\hline No & \multicolumn{1}{c}{ Pertanyaan } & Ya & Tidak \\
4 & Apakah anda bisa membuat kompos sendiri? & $17(100 \%)$ & - \\
5 & Apakah kegiatan ini dapat meningkatkan pengetahuan anda? & $17(100 \%)$ & - \\
6 & Apakah materi yang diberikan bisa anda pahami dengan baik? & $17(100 \%)$ & - \\
7 & Apakah hasil kegiatan pelatihan ini dapat bermanfaat bagi anda? & $17(100 \%)$ & - \\
8 & Apakah anda merasa semangat dengan pelatihan yang diberikan? & $17(100 \%)$ & - \\
9 & Apakah kegiatan ini merupakan hal yang menarik bagi Anda? & $17(100 \%)$ & \\
\hline
\end{tabular}

Dari rekapitulasi angket angket posttest respon peserta pelatihan terhadap kegiatan pengabdian peningkatan keterampilan mahasiswa dalam pengelolaan sampah organik untuk mewujudkan green campus diperoleh data bahwa seluruh responden senang mengikuti pelatihan pembuatan kompos dan sejenisnya hal ini terlihat dari jawaban responden 100\%. Jasminarni dan Said (2015) mengatakan bahwa dengan kegiatan IbM ini menjadikan solusi untuk menanggulangan masalah sampah yang ada disekolah atau disekitarnya.

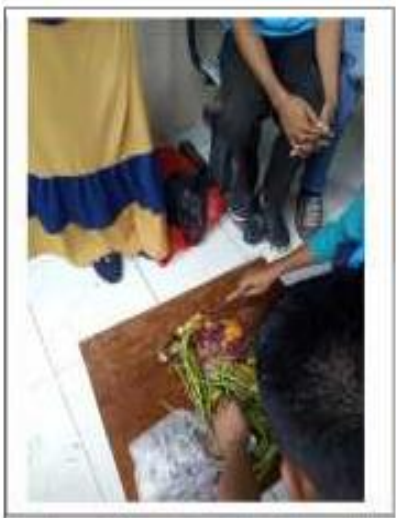

Gambar 1. Proses Pembuatar Pupuk Kompos

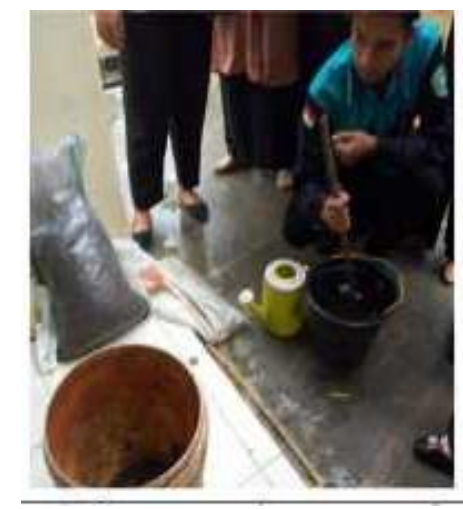

Gambar 2. Proses Pembuatan Pupuk Kompos

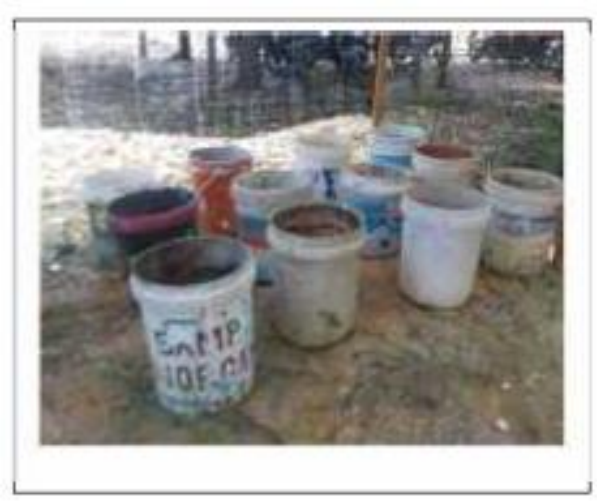

Gambar 2. Kompos Yang Sudah Selesai Diproses

\section{KESIMPULAN}

1. Dengan adanya kegiatan peningkatan ketrampilan mahasiswa ini memberikan dampak yang positif bagi mahasiswa dengan mengelolah sampah yang ada disekitar kampus.

2. Hal ini dapat dijadikan pemasukan bagi mahasiswa sehingga dapat dipergunakan untuk biaya pendidikan karena dapat dijadikan produk andalan kampus.

\section{DAFTAR PUSTAKA}

[1] Sejati. (2009). Pengolahan Sampah Terpadu dengan Sistem Node, Sub Point, Center Point. Kanisius. Yogyakarta.

[2] Jasminarni dan Said, Y, M. (2015). IbM pengolahan Limbah Sampah Organik Sebagai Pupuk Kebun Lingkungan Sekolah di Kabupaten Muaro Jambi. Jurnal pengabdian Pada masyarakat. Vo. 30 No. 1

[3] Karmanah., Dyah, B.W dan Abdul, R.R. (2016). IbM Pengelolaan Sampah Rumah Tangga Sebagai Upaya Menciptakan Lingkungan Pro Iklim. Seminar Nasional dan Gelar Produk.

[4] Suparmini, Nurul, K., Dyah, R, S., Agus, S., \& Sriadi, S. (2013). Laporan Pengabdian Kepada Masyarakat. Pelatihan Pengelolaan Sampah Rumah Tangga dengan Metode Komposting di Desa Bayu Rejo Kecamatan Tempel Kab. Sleman. 